\title{
THE NEW EU ECONOMIC GOVERNANCE: VERTICAL AND HORIZONTAL POWER SHIFTS
}

\author{
FRANK NAERT \\ frank.naert@ugent.be \\ Ghent University
}

\begin{abstract}
The euro crisis made visible the omitted stage in the European integration process. The EU jumped from the common market straight to the monetary union, neglecting the formation of the economic union. The new EU economic governance is a combination of a vertical shift of competences, i.e. from one level of government to another level, and a horizontal shift of powers and competences, i.e. from elected governments to unelected government bodies entrusted with (parts of) government policies, from discretionary policy towards rules. The purpose of this paper is to analyze the new EU economic governance within the conceptual framework of these vertical and horizontal shifts. This two-dimensional approach offers a better analytical tool than the more traditional one-dimensional fiscal federalism approach. In the first part of the paper the focus is on the policy domains that are the objects in the shifting process. Budgetary policy mainly is at stake, but also banking regulation and monetary policy are partly involved. The second part of the paper deals with the relevant aspects of the theories on the division of powers along vertical and horizontal lines. The fiscal federalism approach to vertical separation and the time consistency theory on the horizontal distribution of power are briefly exposed. In the third part the relevant aspects of the new EU economic governance of the European semester, six-pack, two-pack and fiscal compact are presented and put into our framework of vertical and horizontal power shifts.
\end{abstract}

JEL codes: E58; H77; L38

Keywords: fiscal federalism; discretion; rules; economic governance

"Un train peut en cacher un autre."

\section{What Should Be Governed?}

The subject of this paper is the new EU economic governance. Depending on the source the meaning of this concept tends to be different. At all times supervising budgetary and macroeconomic policy is part of it. This is the so- 
called "fiscal union." Also a stronger control of financial institutions, the socalled "banking union," usually falls under the concept. We also count in the extra dimension in monetary policy since the introduction of so-called "nonstandard" measures. Furthermore the development of a European fiscal capacity with the various mechanisms and institutions (i.e. the European Financial Stabilisation Mechanism, the European Financial Stability Facility and the European Stability Mechanism) created in the wake of the eurocrisis are taken by us to be part of the concept of new economic governance.

This evolvement of economic governance can be regarded as a - retarded - completion of economic union in the Balassa (1961) sequence of integration stages. In this stage the goal is to coordinate or even harmonize economic policies. Balassa himself vaguely mentions the suppression of "restrictions on commodity and factor policies." Economic union precedes "total economic integration." This final stage in integration presumes "the unification of monetary, fiscal, social and countercyclical policies and requires the settingup of a supra-national authority whose decisions are binding for the member states." The monetary union and the introduction of the euro brought about this stage, in a partial sense however since not all EU member states participate and only monetary policy was unified. EU economic governance than fills the gap, giving substance to the "Economic" in Economic and Monetary Union.

This paper focuses on the three policy domains that occupy a central place in the way the euro crisis is approached through the new economic governance of the EU. The euro crisis appears in two forms: on the one hand problems in the financial sector and on the other hand public finance problems.

The banking crisis that emerged late 2007 was caused by risk policies of financial institutions gone wrong and the apparent inability of the authorities to assess the systemic risks. This failure led the governments to the reexamination of financial supervision. Hence the first policy that we include in this paper. The modifications to supervision contain elements of a vertical shift, from national monitoring to European supervision, as well as a horizontal shift, from political authorities to independent bodies.

The approach of the banking problems through government interventions such as state guarantees and recapitalization led to the transmission of the financial crisis to the fiscal domain. Within the euro area, the fiscal problems were also caused by the irresponsible fiscal policies in some Member States such as Greece and Portugal.

In the short-term approach to the euro crisis the European Central Bank was involved. This brings the monetary policy into the picture. This is an example of a policy domain that, on the vertical axis, has moved completely 
to the supranational level, and, on the horizontal axis, is completely situated in the corner of independence.

In the longer term the focus is on the reform of budget rules. The simultaneous vertical and horizontal shift is highly visible here. The new EU economic governance puts its stakes on a Europeanisation of budgetary policy by stiffening the European grip on budget rules, but also by the introduction of stabilization mechanisms and facilities in order to organize financial solidarity between EU member states. Furthermore, plans for the introduction of Eurobonds and the idea to create "a fiscal capacity" (Van Rompuy, 2012) add to this process.

\section{Vertical and Horizontal Power Shifts}

\subsection{Vertical Shifts: Fiscal Federalism}

The problem that the fiscal federalism approach wants to solve is situated in the spatial context in which markets and governments operate. The range of markets is determined by consumer tastes, distances, transport costs, type of product. This range can be different for each individual good or service. As a consequence market failures are also diverse in their spatial dimension. In principle the level of government responsible for correcting a market failure should correspond to the spatial reach of the market in question. In practice the number of government levels is limited, which means that there is no perfect match between the economically relevant spatial reach and the political space where the market failure is tackled. Nonetheless also the number of government levels is not given. New levels are created (levels seldom are abolished) and competences can shift between levels.

Fiscal federalism has as its aim to provide insight into the question of which governmental functions in the economy have to be placed with which government levels. To that purpose a good starting point is the subdivision by Musgrave (1959) of economic functions of government in allocation, redistribution and stabilization. Each of the three policy domains covered in this paper - budgetary policy, monetary policy and banking supervision must be assigned to the three Musgravian functions.

Concerning redistribution the conventional wisdom is that it should be placed at highest level possible. Lower levels of government, considering to engage in redistribution risk to be confronted with inflows of relatively low incomes and outflows of relatively high incomes. On the one hand this would exert an upward pressure on pending and a downward pressure on the tax base and tax income. As distances increase, this kind of unwanted mobility 
is supposed to decrease. The higher the level of redistribution, the longer the distances and the smaller the mentioned kind of mobility.

Another argument in favor of keeping the redistribution as central as possible comes from situations in which personal redistribution cannot avoid income distribution between jurisdictions that is considered too unequal. In that case a central redistribution policy towards local jurisdictions can be needed. A cause of such a situation can be tax bases differing strongly because of differing stages of development. Especially when this occurs within a monetary union and the exchange rate instrument cannot be used to correct imbalances, an internal redistribution can be attractive. Thus it is the known context of the European structural funds, as well as the explicit redistribution system of the Finanzausgleich in Germany and the implicit transfers between Flanders and Walloonia in Belgium.

Macroeconomic stabilization is a function that economist like to reserve for higher levels of government. Stabilization policy quickly looses effectiveness as the economy becomes more open. The more important external trade and financial flows become vis-à-vis the rest of the economy, the bigger the leaks that would be brought about by a stabilization policy through the budget. Stabilization through monetary policy is even more problematic at a lower level since the main instrument of this policy, the control over the money supply, is usually situated at central levels.

In the field of allocation several opinions are possible. Some of these opinions lead to a preference for a lower level of government as preferred level: differences in preferences between jurisdictions, the subsidiarity principle and the Tiebout theorem. Other opinions tend to prefer more centralized levels for the allocation function: the phenomena of tax export, tax competition and spill over effects, and economies of scale in tax collection and in the production of public services. In general the former opinions tend to dominate, so most economists would favor as much decentralization in allocation as is possible.

We know apply these insights from fiscal federalism to the three policy domains in the EU new economic governance. We assume a simple multilevel governance framework with two levels of government: supranational and national (see Table 1).

Table 1 Government policies, functions and levels

\begin{tabular}{llll} 
Supranational level & $\begin{array}{l}\text { budgetary policy } \\
\text { stabilization \& } \\
\text { redistribution } \\
\text { stabilization \& } \\
\text { National level }\end{array}$ & $\begin{array}{l}\text { monetary policy } \\
\text { stabilization }\end{array}$ & $\begin{array}{l}\text { banking supervision } \\
\text { allocation }\end{array}$ \\
\hline
\end{tabular}


Budgetary policy covers the three Musgravian functions. From the theory of fiscal federalism we detain that budgetary policy with stabilization and redistribution as objectives are best situated at a higher level, while budgetary policy aiming at allocation is best situated at a lower level (see Table 1). Monetary policy mainly is a matter of stabilization and is therefore best placed at higher levels of government. The choice of exchange rate system is relevant here. In a system of fixed exchange rates, and a fortiori a common currency system, monetary policy has to be conducted by definition at the level of the fixed rate or currency zone. In a floating rate system the national level can keep its responsibility over monetary policy. The need for banking supervision follows from the contingency of market failure in the form of systemic risk. Here government has to avoid the external effects of eventual bankruptcy of a financial institution. The degree of market integration with other countries then determines which level of government is best suited for banking supervision. The higher the degree of market integration, the higher the level at which supervision should be organized.

Anticipating on the next paragraph, it becomes clear by now that the degree of market integration within the European Union has an important impact on the decision on which level responsibility for the three policy domains should be placed. The creation of a single market in the European Union has caused the Europeanization of financial markets and institutions and the need to control them on a European level. The creation of the monetary union caused the obvious shift of monetary policy to the supranational level and initiated the less obvious and much discussed shift of budgetary powers. The euro crisis speeded up this discussion.

\subsection{Horizontal Shifts: Credibility, Rules and Independence}

The interest taken by academics in the credibility of economic policy originated in the eighties. Especially the numerous exchange rate alignments in the European Monetary System created a fertile breeding ground for this attention. The credibility of central banks and the role therein of independence from politics took a central place in this discussion. The credibility issue was however not confined to exchange rate policy but was quickly applied to the general macroeconomic policy. It entered the domain of fiscal policy through the introduction of budgetary rules. By the end of the $20^{\text {th }}$ century the interest in credibility spread to microeconomic policy areas, leading to insights in how best to address the regulation of economic sectors such as network industries. Credibility emerged as an important concept, as well as independence as a condition for credibility.

The "credibility hypothesis" is stated extensively in the literature (Gilardi, 2002; Gilardi 2006, Genoud, 2003, Larsen et al. 2006). Credibility is a valuable 
asset for governments, because rational individuals base their expectations on all economically available information at the moment of decision. Rational actors' beliefs are influenced by beliefs about future actions of policy makers. Credibility is the capacity for inspiring belief. A credible policy is a policy worthy of being accepted as true or reasonable. A politician/government/ regulator is credible when agents believe he will fulfill his promises. Credibility is needed when coercion is not an option for policy makers.

Connected to credible policy making is the time-inconsistency problem. A typical situation is posed by investment decisions in a liberalized setting. These decisions are made by private investors and not longer by government itself or by public companies. Another typical situation is when economic actors make decisions about wages and prices in the context of the goals for monetary policy set by government.

This latter kind of situation was the starting point for the literature on central bank independence. In a seminal paper, Kydland and Prescott (1977) stress the importance of an independent central bank because there is a potential conflict between policymakers' discretion and policy optimality, called the "time inconsistency of policy." Often policymakers need to credibly bind themselves to a fixed and pre-announced course of action. Otherwise the danger exists that policy is altered because of changes in preferences of policymakers (Gilardi 2006).

In a more general sense a time consistent policy is a policy that will be sustained as circumstances change over time. Adhering to a policy rule may require pursuing a policy at a particular point in time that is not optimal at that time. In contrast, policy that is time inconsistent will be reversed in the future due to predictable developments over time. In a typical democratic setting time inconsistency will be the rule rather than the exception as democracies are characterized by the short term time horizons of politicians in view of elections and by the accompanying changes of the ruling party or coalition.

A device to guarantee a time consistent policy is to create a commitment mechanism for removing the risk of opportunistic policy in particular contingencies. Usually two devices are available. The first is to delegate decision making to an independent institution. Independence for regulators can act as such a commitment mechanism (Gilardi, 2002). In this way, governments prohibit themselves and future policymakers from taking these short-sighted decisions. They "tie their hands," so it will be politically more costly to overrule a decision made by an agency. Thus policymakers cannot use discretionary policy as a mechanism to favor a particular interest group. The more independent an agency is, the more credible the policy is for stakeholders, potential investors, consumers, etc. Policymakers delegate to increase the credibility of their policy commitments. A second device is to install policy 
rules. Politicians give up their discretion in decision-making and commit to a policy rule that was set previously by another government at the same of or at a higher level. In that way politicians again tie their hands to analogous effects as with delegation.

For the purpose of this paper the relevant policy domains to study with respect to delegation and rules are financial supervision that constitutes a part of regulatory policy, fiscal policy and monetary policy.

In regulatory policy, especially in the aftermath of utilities privatization and liberalization (Gilardi 2002 and 2006), credibility is mainly pursued by delegating competences to independent institutions. Policy makers have incentives to promise a favorable regulatory environment to attract investors, necessary for fostering competition. Once relatively irreversible investments are made, policymakers may be tempted to go back on their commitment. Rational investors will not invest in the first place, creating a suboptimal situation. In the literature this is called the "hold up" problem (Kirkpatrick, Parker \& Zheng 2006). To avoid this problem governments all over the world have established independent regulators to take over the implementation of regulatory policy. In the field of finance independent supervisors have been around for several decennia.

In the field of fiscal policy the problem has mainly been tackled in another way, namely by introducing fiscal rules. This does not forego that delegation of parts of the fiscal policy making (f.i. forecasting growth) has taken place in some countries at some points in time. The objective of fiscal policy is to run the budget in the interest of society along the three Musgravian functions. The budget is the instrument of fiscal policy. It has itself the characteristic of a common pool resource, in the sense that exclusion of various special interest groups calling on the budget is difficult while this appeal is rival. This feature leads to so called deficit bias, meaning that the frequency of negative budget balances tend to be higher than the frequency of positive balances. The perspective of spending more and taxing less in a recession is attractive to politicians. In that case they can meet the multiple budgetary wishes of interest groups and voters without having to let pay the price in the form of higher taxes, all this in hope of an electoral return. The inverse does not happen in an overheated economy: against the prescription of functional finance no surplus is created. Higher taxes and lower spending are not very attractive from an electoral point of view. Politicians steer clear of them and infect public finance wit a deficit bias. This deficit bias reflects a time inconsistency problem in the sense described in the preceding paragraph whereby the long-term discipline objective is systematically overlooked when short-term discretion is being used.

The adoption of fiscal rules has been considered as the instrument of choice to deal with deficit bias (Debrun \& Kumar 2008). The history of 
fiscal rules is impressive. All over the world over the last decennia countries have experimented with fiscal rules. A fiscal rule is defined as "a permanent constraint on fiscal policy, expressed in terms of a summary indicator of fiscal performance" (Kopits \& Symansky 1998). There are rules available on deficit limits, spending limits, taxing limits, debt limits, etc. (see IMF, 2009). Nevertheless there is no consensus in the literature on whether fiscal rules are a robust remedy against the deficit bias. This is painfully shown by the recent Greek and Irish case, but it was already predicted in tempore non suspecto: "In the particular case of monetary unions, the centralization of monetary policy can reduce individual countries' incentives for fiscal discipline. Normally, the unpleasant prospect that excessive public debt may ultimately increase future inflation and interest rates is likely to impose some selfrestraint on governments. In a monetary union, however, this effect is likely to be diluted, particularly for the smaller members of the union, and could lead to excessive debt accumulation (Beetsma and Bovenberg, 1999). In addition, monetary unions can entail a moral hazard related to the greater likelihood of a bailout by other member states or by the common central bank" (Debrun et al. 2009).

This brings us to delegation to fiscal institutions as an alternative or a complement to fiscal rules. Debrun et al. (2009) make a distinction between two types of fiscal institutions. The first type are called fiscal councils. These councils take up tasks of independent analysis, forecasts or normative judgments and in this way help to improve fiscal policy. Van Meensel (2008) attributes either positive or normative functions to fiscal councils. To the first category belong institutions, which make up macroeconomics forecasts, public finance forecasts, impact analyses of shocks and policies. The second institutional category makes policy recommendations and/or assessments of fiscal performance in comparison with targets. Neither type of fiscal councils receives any specific authority over fiscal policy (Bogaert et al. 2006). Fiscal councils add value to the policy process by affecting policymakers' incentives and motivations. There can be an impact through public debate of the findings of fiscal councils. There is evidence suggesting that fiscal councils of the second category generally contribute more to fiscal discipline than those of the first category (Debrun et al. 2009).

In monetary policy delegation as well as policy rules have been used extensively. Nowadays more or less independent central banks are standard procedure in most Western countries, while rules - in this context usually called targets - are widely used. Taylor (2013) points to the eighties and nineties, a period of "the more rule focus on price stability and the closer adherence to simple predictable policy rules," while since then "monetary policy became much less rule like." Goodfriend (2012) and Issing (2012) comment on the shifts in independence of central banks in the long term. 


\section{Transformation of EU Economic Governance}

\subsection{New European Fiscal Rules and Involvement}

The Stability and Growth Pact as it was conceived since 2005 was not up to the task of avoiding the budgetary problems related to the euro crisis. Although there have been tens of violations of the pact, there have been very few sanctions. In the wake of the euro crisis the insight developed that the absence of a really enforceable and European wide framework for fiscal policy was responsible for this crisis. To give substance to this so-called "economic governance" takes time, however, given the complicated decision making system in the European Union. Moreover this economic governance is not limited to budgetary policy ("fiscal governance") in the member states. It also includes broader measures to tackle macroeconomic imbalances.

The framework for budgetary policy in the new EU economic governance consists of

- The European semester

- The measures of the so-called "six-pack"

- The "fiscal compact"

- The measures of the "two-pack."

The system of the European semester was used for the first time in 2011 and introduces a coordinated cycle for the supervision of the economic and fiscal policies of the member states. Before economic policies of the member states were discussed in the EU in the spring, separately from the discussions on fiscal policies that were held in the autumn. The European semester combines the European governance in the first semester of the calendar year. Following the European semester the member states can take necessary decisions on their fiscal policies for the following fiscal year in the "national" semester. In this way the European semester brings forward and strengthens the supervision of the stability and convergence programs submitted by the member states. Starting point is the Commission's January growth report. In February come the debates and briefing in the thematic Councils of Ministers and the European Parliament. The European Council then decides on the priorities in March and in April member states submit their stability or convergence program. In June the European Council approves the countryspecific recommendations.

The "six-pack" consists of five regulations and one directive. They are in force since December 2011. The measures in the six-pack start from the provisions of the Stability and Growth Pact and reinforce and supplement them. The preventive arm of the pact is reinforced by an improved monitoring of the medium term structural targets. An expenditure benchmark will be 
used in function of the medium term potential growth. A sanction in the form of an interest-bearing deposit of $0.2 \%$ of GDP is foreseen for noncompliant member states. The strengthening of the corrective arm mainly consists of the operationalization of the debt criterion. The excess of the debt ratio above $60 \%$ of GDP has to decrease by $1 / 20$ yearly. An important modification was implemented in the decision making process on sanctions in the excessive deficit procedure. Sanctions are now decided upon by reversed qualified majority voting, meaning that in the Ecofin Council of Ministers a sanction can only be avoided when a qualified majority is found.

The six-pack also contains a directive that has to be transposed by 2014 . This directive envisages the obligation for the member states to involve an institution independent from politics in certain aspects of the budgetary process. Finally the six-pack also foresees a closer monitoring of macroeconomic imbalances. The Commission introduced "scoreboards" wherein important macroeconomic indicators for the member states are listed and compared to preset targets.

The "fiscal compact" actually is the budgetary part of the broader Treaty on Stability, Coordination and Governance concluded on 2 March 2012 by 25 EU member states. The United Kingdom and the Czech Republic opted to stay out of this treaty. The Treaty came into force on the $1^{\text {st }}$ of January 2013. It is an intergovernmental agreement and as such is not a part of the EU legislation. The fiscal compact introduces the "golden rule" whereby the structural fiscal deficit may not be higher than $0.5 \%$ of GDP (1\% for member states with a debt ratio exceeding $60 \%$ of GDP). There is an automatic correction mechanism, with escape clauses however for exceptional economic conditions. Independent budgetary councils at the member states level have to control the compliance with this rule. The rule has to be implemented in national legislation and the European Court of Justice can impose a fine of $0.1 \%$ of GDP in case this implementation is not properly done.

On top of these measures two other regulations came into force in May 2013. One regulation again concerns an explicitation of the Stability and Growth Pact and specifically of the excessive deficit procedure. The role of numerical fiscal rules and of the independent fiscal councils that have to monitor the compliance with the rules is specified. This is done against the background of a timeline that explicits the timing of the submission of draft budgetary plans and the assessment of these plans by the European Commission. The second regulation concerns strengthened surveillance of countries in difficulties.

The new EU economic governance in the fiscal domain not only deals with stricter rules, monitoring and sanctioning. It also addresses the problem of financial solidarity between member states. There are several aspects of a stronger financial involvement of the EU in the budgetary function. The 
acute crises in Greece, Portugal, Ireland, Spain and Cyprus have inspired the European Union to set up financial rescue operations. The European Financial Stabilisation Mechanism (EFSM) supports all EU Member States, with current focus on euro area Member States, up to EUR 60 billion, activated for Ireland for up to EUR 22.5 billion and for Portugal for up to EUR 26 billion. The European Financial Stability Facilty (EFSF) was also created in response to the financial crisis that began in 2008 and provided temporary stability support to euro-area Member States. It is a société anonyme set up under Luxembourgish law on 7 June 2010, as part of the May 2010 package, mandated to provide financial assistance on a temporary basis and thus able to enter into new programs only until 30 June 2013; although the EFSF will continue to service existing commitments thereafter. The EFSF provides financial assistance to euro area Member States, linked to appropriate conditionality. It obtains financing by issuing bonds or other debt instruments on the financial markets backed by guarantees of the shareholder Member States. These guarantees total $€ 780$ billion. As a result of the Greek, Irish and Portuguese programs, the EFSF has effective guarantees totaling $€ 726$ billion that provide a lending capacity of $€ 440$ billion. Contrary to the EFSF the European Stability Mechanism (EMS) is a permanent international financial institution that assists in preserving the financial stability of the European Union monetary union by providing temporary stability support to euro area Member States. The ESM was finally inaugurated on 8 October 2012 upon completion of the ratification process by the participating euro area Member States. The ESM issues bonds or other debt instruments on the financial markets to raise capital to provide assistance to member states. Unlike the EFSF, which was based upon euro area member state guarantees, the ESM has a total subscribed capital of $€ 700$ billion provided by euro area member states. $€ 80$ billion of this is in the form of paid-in capital with the remaining $€ 620$ billion as callable capital. This subscribed capital provides a lending capacity for the ESM of $€ 500$ billion.

Besides these rescue operations already in place the European Union is discussing further ideas on expanding its budgetary role. Van Rompuy (2012) launched the idea of "establishing a well-defined and limited fiscal capacity to improve the absorption of country specific economic shocks, through an insurance system set up at the central level." The European Commission in December 2011 published a green paper on "the feasibility of introducing Stability Bonds" (European Commission 2011). One of the ideas proposed is to let member states finance the part of their government debt under $60 \%$ of gdp through the common issuance of bonds. This would enable the member countries with a lower creditworthiness to benefit from the lower interest rates paid in the capital markets by more creditworthy member states for that 
part of their debt. The debt above $60 \%$ of GDP should still be financed by individual issuance.

Last item to mention is a proposal by the former president of the ECB, Jean-Claude Trichet, who proposes to replace the sanctioning fines in case a member state has an excessive deficit by fiscal measures taken proposed by the European Commission and endorsed by the European Council and the European Parliament (De Standaard 2013).

\subsection{The Formation of a Banking Union}

The banking crisis in the Euro Area and wider has led the EU to undertake of steps by the EU towards the creation of a banking union. The intention of a banking union is to transfer to the European level the mechanisms of financial supervision and the prevention and remediation of banking crises.

Elliot (2012) points at the following more detailed reasons for a banking union:

- Dealing with existing bank weaknesses that contributes to the euro crisis;

- Reducing the risk that banking will contribute to later stages of the euro crisis;

- Restoring the effectiveness of ECB monetary policy;

- Reintegrating the European banking system;

- Fixing long-standing problems with the single market in EU banking.

The Euro Area poses specific risks, as pooled monetary responsibilities have spurred close economic and financial integration. Cross-border spill-over effects in the event of bank crises are more likely to occur. Moreover the link between sovereign debt and bank debt and the vicious circle which has led to taxpayers' money being used to rescue banks in the EU has to be broken. Next there is an increasing risk of fragmentation of EU banking markets. This risk significantly undermines the single market for financial services and impairs the effective transmission of monetary policy to the real economy throughout the Euro Area.

Before elaborating on the way the EU tackles these problems, a short general introduction on banking supervision is warranted. The role of government regarding external effects in the financial sector has two dimensions. The first dimension is macroprudential supervision that has to keep an eye on the stability of the financial system. Stability is the capacity of the financial system to withstand shocks and financial imbalances. Disturbances in financial intermediation should be avoided by this kind of supervision at the same time guaranteeing an efficient transmission of savings to profitable investments. The second dimension is microeconomic supervision. This kind of supervision is in the first place responsible for the solidity of individual 
financial institutions (microprudential supervision). It concerns capital requirements as laid down in the successive versions of the Basel Agreements (Basel I, Basel II, Basel III). In the second place it deals with the conduct of business supervision aimed at the way financial institutions deal with customers. To this purpose supervisors usually introduce on the supply of information to customers, on the integrity of management and staff, acceptable commercial practices, marketing practices, etc. (Llewellyn, 1999).

In a first approach the EU undertook to coordinate the supervision of individual member states over their financial sector. To this end the European System of Financial Supervision (ESFS) was established at the beginning of 2011 to implement the de Larosière Group's proposed greater integration of European financial supervision. This supervisory network consists of the national supervisory authorities of the $27 \mathrm{EU}$ member states, the three new European Supervisory Authorities (ESAs), their Joint Committee and the European Systemic Risk Board (ESRB). Together with the national supervisory authorities, the three ESAs (the European Banking Authority (EBA), the European Insurance and Occupational Pensions Authority (EIOPA) and the European Securities and Markets Authority (ESMA)) help to improve the quality and coherence of microprudential supervision in the EU and to strengthen cross-border supervision.

However when the euro crisis deepened this step quickly appeared to be insufficient. "Coordination between supervisors is vital but the crisis has shown that mere coordination is not enough, in particular in the context of a single currency and that there is a need for common decision making" (European Commission, 2012b).

The next answer to the crisis was the creation of a banking union. To that end the Commission proposed to establish a Single Supervisory Mechanism (SSM). A unanimous agreement was reached on this proposal in the ECOFIN Council on 13 December. Following trilogue negotiations during January and February, the Parliament, the Council and the Commission reached agreement on the package on 19 March 2013 (European Commission 2013).

The establishment of the Single Supervisory Mechanism (SSM) is the first step towards a banking union. Next steps will include also a single bank resolution mechanism, underpinned by a single rulebook and a common deposit guarantee scheme.

The SSM applies to all the euro-area member states and is open to the participation of other member states. To that end these non-euro area member states may establish a close cooperation between their supervisory authorities and the ECB.

The Regulation establishing the SSM confers key supervisory tasks and powers to the ECB over all the 6000 credit institutions established within the euro area. The ECB carries out its tasks within a SSM composed of the ECB 
and national competent authorities. The ECB shall ensure the coherent and consistent application of the Single rulebook in the euro area. It will directly supervise banks having assets of more than EUR 30 billion or constituting at least $20 \%$ of their home country's GDP or which have requested or received direct public financial assistance from the EFSF or the ESM. Less significant banks will be supervised by national supervisors, while these supervisors will be under the monitoring of the ECB.

The ECB may at any moment decide however to directly supervise one or more of these credit institutions to ensure consistent application of supervisory standards. The work of the national supervisors is integrated into the SSM. For instance, the ECB will send instructions to national supervisors, and national supervisors have a duty to notify the ECB of supervisory decisions of material consequence.

The governance structure of the ECB will consist of a separate Supervisory Board supported by steering committee, the ECB Governing Council, and a mediation panel to solve disagreements that may arise between national competent authorities and the Governing Council. Clear separation between the ECB's monetary tasks and supervisory tasks is fully ensured.

For cross-border banks active both within and outside member states participating in the SSM, existing home/host supervisor coordination procedures will continue to exist as they do today. To the extent that the ECB has taken over direct supervisory tasks, it will carry out the functions of the home and host authority for all participating Member States.

The rules on the functioning of the EBA will be adapted and its role reinforced. The EBA will continue developing the single rulebook applicable to all 27 member states. In order to foster consistency and efficiency of supervisory practices across the whole Union, it will develop a single supervisory handbook. It will also ensure that regular stress-tests are carried out to assess the resilience of European banks.

There will be safeguards for non-euro zone member states by means of double majority voting requirements for EBA decisions on mediation and on technical standards. This ensures that decisions are backed by both a majority of the participating and the non-participating Member States.

\subsection{The Transformation of Monetary Policy}

Monetary policy in the euro zone lies in the hands of the European System of Central Banks (ESCB). It comprises the European Central Bank (ECB) and the national central banks. The ECB is a supranational institution that is moreover to a great extent independent from EU political decision-making. The highest decision making body of the ECB is the Governing Council comprising the members of the Executive Board and the governors of the 
national central banks of the euro area countries. The Executive Board consists of six members, the president, the vice-president and four members, all of them chosen for their recognized professional experience in monetary and banking matters. They are appointed by common accord of the governments of the euro area at the highest level. The Governing Council and the Executive Board are presided by the president of the ECB (momentarily Mario Draghi). The third decision-making body is the General Council, comprising of the president and vice-president of the ECB and the presidents of the central banks of all EU member states. The ECB and the national central banks in the euro area form the Eurosystem.

The primary objective of the Eurosystem is to maintain price stability. In addition it has to support the general economic policy of the EU, but price stability has absolute priority. This unique objective simplifies the strategy of the Eurosystem vis-à-vis countries were central banks have to pursue multiple objective (cf. the Fed in the US).

An important feature of the statutes of the system is the independence of the ECB from political government. Personal as well as functional independence are guaranteed. The personal independence is secured by the procedure for the appointment of the members of the Executive Board and of the governors of the national central banks. The members of the Board are appointed for a non-renewable term of eight years and the governors for a term of five years. They can only be removed by the Court of Justice in case of incapacity or of serious misconduct. Functional independence is guaranteed by Article 7 of the statutes of the ESCB: "Neither the ECB nor a national central bank nor any member of their decision making bodies shall seek or take instructions from community institutions or bodies, from any government of a member state or from any other body." It is not permitted for the Eurosystem to make loans to governments. That the ECB is indeed highly independent is seen in a comparison of central bank independence based on five indicators by De Haan (1997). The ECB scores the maximum on three indicators and just below the maximum for the remaining two indicators.

Price stability is defined as a year-on-year increase of the Harmonised Index of Consumer Prices in the euro area of below 2\%. The operational variables for monetary policy used by the ECB are the interest rates on the money market. To steer these interest rates in the money market the ECB has at its disposal open market operations, standing facilities and reserve requirements. The most important instruments of open market operations are the main refinancing operations that provide liquidity with a frequency and maturity of one week. The interest rate for this liquidity - the main refinancing operations rate - is the central rate in the system and attracts a lot of media attention. In May 2013 it was put at $0.50 \%$. Besides this facility the ECB also holds longer-term refinancing operations with maturities of three months. The stand- 
ing facilities offer lending and deposit facilities for the overnight money of banks. The marginal lending facility allows banks to obtain liquidity, while the deposit facility allows them to deposit superfluous overnight money. For the first facility a rate of $1 \%$ was valid in May 2013, while the rate for the deposit facility was $0 \%$. The reserve requirements oblige banks to hold minimum reserves in accounts with the national central banks ( $2 \%$ of deposits until the beginning of 2012, since then $1 \%$ ).

Since the financial crisis the ECB has ventured unknown paths. Besides price stability (and the brand new supervisory tasks, cf. supra) avoiding systemic risk by providing financial means has become important. New facilities were designed by the ECB as well for financial institutions as for governments of member states.

From the start of tensions in the interbank markets in August 2007, the ECB accommodated the funding needs of banks. The banks needed to build up daily liquidity buffers so as to reduce uncertainty about their liquidity positions. In particular, the ECB de facto provided unlimited overnight liquidity to banks, allocating $€ 95$ billion on the first day. Later on, the ECB conducted supplementary refinancing operations with maturities of up to 6 months, compared with a maximum of 3 months in normal times. Temporary swap lines were established with other central banks, primarily to address the mounting pressure in short-term US dollar funding markets. As a result, the tensions in the short-term segment of the euro area money market abated considerably.

Following the bankruptcy of Lehman Brothers on 15 September 2008, the uncertainty about the financial health of major banks worldwide led to a collapse in financial activity. Banks built up large liquidity buffers, while shedding risks from their balance sheets and tightening loan conditions. Given the crucial importance of banks for the financing of the euro area economy, this situation was alarming in view of a high risk of a credit crunch and a high risk of the central bank's inability to steer monetary conditions.

The ECB, like other major central banks, rapidly reduced its key interest rates to historically low levels, but a key element of its response to retain effectiveness in influencing monetary conditions consisted of non-standard policy measures. The ECB adopted a number of these non-standard measures to support financing conditions and credit flows to the euro area economy over and beyond what could be achieved through the normal reductions in key interest rates alone.

The main components of these measures concerned a fixed-rate full allotment tender procedure for all refinancing operations during the financial crisis and the extension of the maturity of liquidity provision. The maximum maturity of the longer-term refinancing operations (LTROs) was temporarily extended (to 12 months in June 2009). In combination with the first element, 
this contributed to keeping money market interest rates at low levels. Besides these two elements other features of the ECB approach included the extension of collateral eligibility, currency swap agreements and the introduction of a covered bond purchase program (CBPP). The aim of this last program was to revive the covered bond market, which is a primary source of funding for banks in large parts of the euro area.

The evidence available suggests that the non-standard measures taken in October 2008 have been instrumental in stabilizing the financial system and the economy, as well as in ensuring price stability.

In early 2010 the euro area sovereign debt crisis began with acute market expectations about a possible Greek sovereign default, with a risk of impact on Ireland, Portugal, and even Spain and Italy. In May 2010 some secondary markets for government bonds began to dry up completely; large-scale sale offers faced virtually no buy orders and yields reached levels that would have quickly become unsustainable for any sovereign. To help calm the market down and support a better functioning of the monetary policy transmission mechanism, the ECB established its Securities Markets Programme (SMP). Under the SMP, interventions could be carried out in the euro area public and private debt securities markets, strictly limited however to secondary markets.

When the sovereign debt crisis struck Italy and Spain in the summer of 2011 the ECB decided to "actively implement its Securities Markets Programme" (Statement by the ECB President, 7 August 2011) that had been dormant for several months. Significant and sustained interventions at varying intensity in the following weeks temporarily eased the situation in government bond markets.

In the autumn, however, the euro area banking system came increasingly under strain, calling for a response. The ECB provided banks not only with a short-term liquidity support but also with a sufficient perspective so that they would maintain credit lines.

Key in this response were the two 3-year Long Term Refinancing Operations. The assignments took place on 21 December 2011 and 29 February 2012 respectively. They took the form of fixed rate tenders at an interest rate equal to the main refinancing rate averaged over the entire maturity. The Eurosystem assigned $€ 489$ bln in the first transaction and $€ 530$ bln in the second one. Since these transactions partly replaced operations coming to maturity, the net injection of liquidity amounted to $€ 210$ bln and $€ 311$ bln respectively.

On 6 September 2012 the ECB decided on a scheme to intervene in secondary sovereign bond markets subject to strict and effective conditionality, the so-called Outright Monetary Transactions OMT. The effectiveness of these OMT crucially depends on member states taking the necessary steps to contribute to the stability of the euro area. This is made clear with the strict 
conditionality of the OMT. The OMT differ from the SMP in the strict conditionality of the former.

It should be stated clearly that until now no changes in terms of statutes of the ESCB/ECB have been made concerning the conduct of monetary policy. The changes made concern the assigning of a supervisory role to the $\mathrm{ECB}$, with a clear firewall between monetary policy and the supervisory role. Moving away from the legislative framework one can however see a broadening of the action radius of the ECB. The avoidance of systemic risk through LTRO and OMT has taken the ECB in the field of fiscal policy. Although denied by the ECB (Draghi 2013) this move elicits questions on the independence of the ECB. Especially with OMT, where bonds issued by member states governments are bought by the ECB on the secondary market, the ECB seems to engage in policies that accommodate the governments in their fiscal policies, instead of remaining in its own field of monetary policy.

\subsection{Analysis in Terms of Horizontal and Vertical Shifts}

The preceding paragraphs offer a descriptive account of the transformations in the EU economic governance. The next step is to systematize these transformations. We do this by listing the concrete elements of the mentioned transformations that contain the kind of shifts discussed in section 2. This is done in table 2 were 37 shifts of power are enumerated. Of these 37 shifts 19 are in the domain of fiscal union, 8 in banking union and 10 in monetary policy. It should be noted that the nature of these power shift is very heterogeneous. Some power shifts are enacted in legislation (f.i. operationalization of the debt criterion), others are de facto policy measures already implemented (f.i. the Outright Monetary Transactions), yet others exist only in proposals (f.i. Eurobonds). 
Table 2 List of power shifts

\begin{tabular}{|c|c|c|c|}
\hline & Changes (shifts) & Code & Status \\
\hline \multirow[t]{19}{*}{ Fiscal union } & operationalization of debt criterion & FU1 & in force \\
\hline & new expenditure rule & FU2 & in force \\
\hline & $\begin{array}{l}\text { need to improve structural balance with at least } 0,5 \% \text { of GDP } \\
\text { annually }\end{array}$ & FU3 & in force \\
\hline & limit of $-0,5 \%$ of GDP on structural balance & FU4 & in force \\
\hline & $\begin{array}{l}\text { interest bearing deposit of } 0,2 \% \text { of GDP in case of significant } \\
\text { deviation of MTO }\end{array}$ & FU5 & in force \\
\hline & extra monitoring under EDP & FU6 & in force \\
\hline & fines come earlier at $0,2 \%$ of GDP & FU7 & in force \\
\hline & fine to maximum $0,5 \%$ of GDP in case of statistical fraud & FU8 & in force \\
\hline & $\begin{array}{l}\text { decisions on sanctions in EDP with reversed qualified majority } \\
\text { voting }\end{array}$ & FU9 & in force \\
\hline & earlier and higher surveillance for problem countries & FU10 & in force \\
\hline & $\begin{array}{l}\text { national budgetary processes have to be based on independent } \\
\text { macro-economic projections }\end{array}$ & FU11 & in force \\
\hline & member states have to introduce numerical fiscal rules & FU12 & in force \\
\hline & $\begin{array}{l}\text { member states have to establish independent fiscal councils to } \\
\text { monitor compliance with fiscal rules }\end{array}$ & FU13 & in force \\
\hline & European Financial Stabilization Mechanism & FU14 & in force \\
\hline & European Financial Stability Facility & FU15 & in force \\
\hline & European Stability Mechanism & FU16 & in force \\
\hline & issuing of Stability Bonds & FU17 & $\begin{array}{l}\text { proposal } \\
12 / 2011 \\
\end{array}$ \\
\hline & establishing EU fiscal capacity & FU18 & $\begin{array}{l}\text { proposal } \\
12 / 2012 \\
\end{array}$ \\
\hline & establishing European Ministry of Finance to impose sanctions & FU19 & $\begin{array}{l}\text { proposal } \\
04 / 2013\end{array}$ \\
\hline \multirow[t]{8}{*}{$\begin{array}{l}\text { Banking } \\
\text { Union }\end{array}$} & $\begin{array}{l}\text { establishing European Systemic Risk Board for } \\
\text { macroprudential supervision }\end{array}$ & BU1 & in force \\
\hline & establishing European Banking Authority (+ EIOPA \& ESMA) & BU2 & in force \\
\hline & $\begin{array}{l}\text { establishing European System of Financial Supervision for } \\
\text { microprudential supervision }\end{array}$ & BU3 & in force \\
\hline & $\begin{array}{l}\text { establishing Single Supervisory Mechanism for banks of } \\
\text { eurozone members }\end{array}$ & BU4 & in force \\
\hline & enforcement of role of EBA & BU5 & decided \\
\hline & single rulebook for entire EU & BU6 & decided \\
\hline & single bank resolution mechanism & BU7 & proposal \\
\hline & common deposit guarantee scheme & BU8 & proposal \\
\hline \multirow[t]{10}{*}{$\begin{array}{l}\text { Monetary } \\
\text { policy }\end{array}$} & unlimited overnight liquidity to banks (August 2007) & MP1 & implemented \\
\hline & $\begin{array}{l}\text { supplementary refinancing operations over } 6 \text { months (rest } \\
\text { 2007) }\end{array}$ & MP2 & implemented \\
\hline & $\begin{array}{l}\text { Long Term Refinancing Operations (LTRO) over } 12 \text { months } \\
\text { (October 2008, June 2009) }\end{array}$ & MP3 & implemented \\
\hline & extension of collateral eligibility (October 2008) & MP4 & implemented \\
\hline & currency swaps (October 2008) & MP5 & implemented \\
\hline & Covered Bond Purchasing Programme (October 2008) & MP6 & implemented \\
\hline & Securities Market Programme (May 2010) & MP7 & implemented \\
\hline & Securities Market Programme revived (summer 2011) & MP8 & implemented \\
\hline & LTRO over 3 years (December $2011 \&$ February 2012) & MP9 & implemented \\
\hline & Outright Monetary Transactions (OMT) (September 2012) & MP10 & implemented \\
\hline
\end{tabular}


Some power shifts have obviously more impact than others, we do not attach weights to the power shifts due to a lack of weighing criterion.

Graph 1 The direction of power shifts

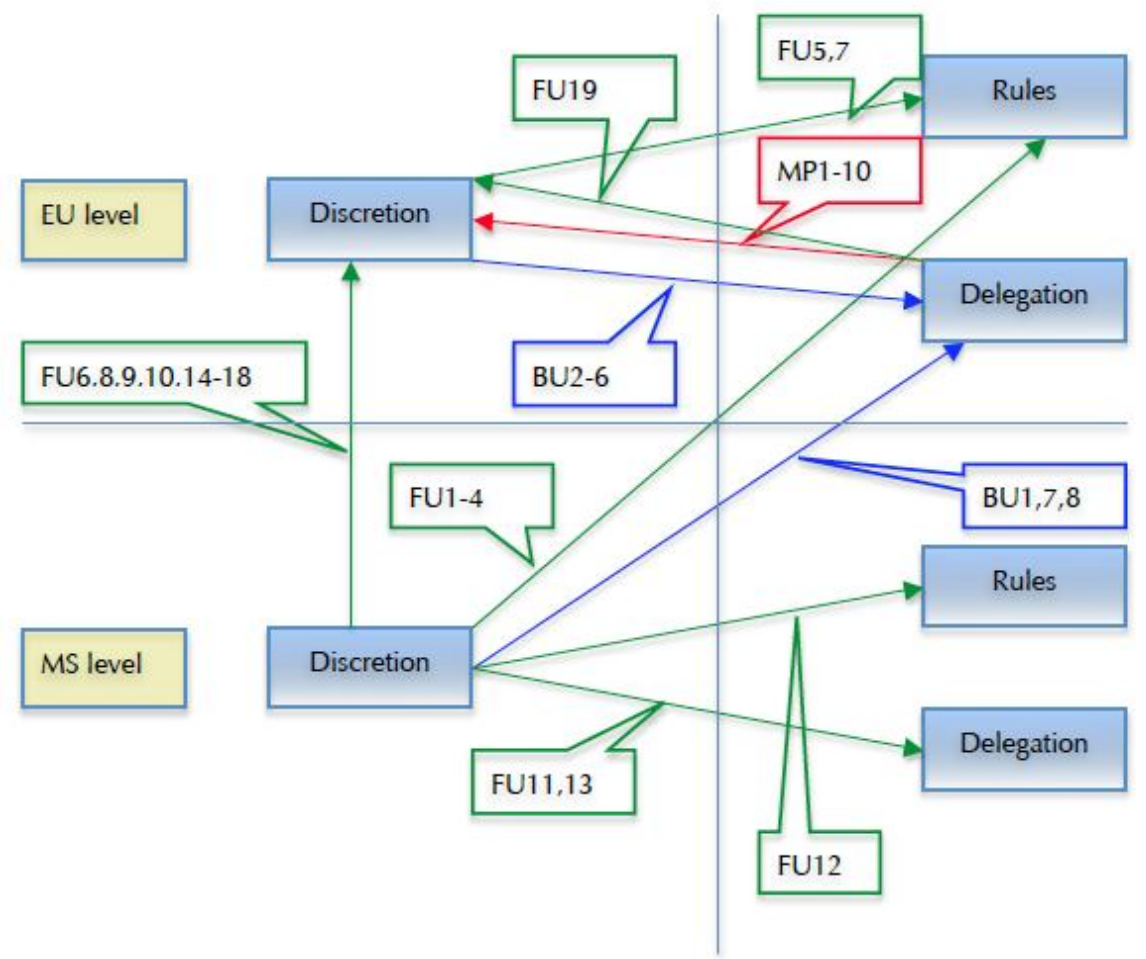

Next we chart the power shifts (see graph 1). The two levels of government are the European and the national level. The three kinds of decision-making are discretion, delegation and rules. Vertical shifts occur between government levels, horizontal shifts between types of decision-making. Diagonal shifts occur when vertical and horizontal shifts are combined. Graph 1 shows that from the moment that the credibility dimension is taken into account, the simple view of a mere vertical power shift from member states to the European Union or the Eurosystem becomes invalid. Instead of observing only upward pointing vertical arrows we see many arrows pointing in other directions. We distinguish the following types:

- From discretion at the MS level to discretion at the EU level

- From discretion at the MS level to rules at the EU level

- From discretion at the MS level to delegation at the EU level

- From discretion at the MS level to rules at the MS level

- From discretion at the MS level to delegation at the MS level 
- From discretion at the EU level to rules at the EU level

- From discretion at the EU level to delegation at the EU level

- From discretion at the EU level to discretion at the EU level

The main impact of these insights is on accountability. Vertical shifts from a member state government with full discretion to a higher European level of government with full discretion poses a problem of accountability in the sense of the perceived democratic deficit of the European Union. An extensive political science literature exists on the European democratic deficit (Majone 1998, Moravcsik 2002, Curtin 2007, Jensen 2009). Horizontal shifts away from discretion to rules and delegation also create a problem of accountability, but in another sense and in another kind of literature. In fact several bodies of literature deal with this problem. There is a body of literature in economics about the accountability of independent central banks (De Haan 2000). There is also literature by economists on accountability of financial supervisors (Quintyn 2011). Finally there is a mainly political science body of literature on the accountability problems of independent regulatory agencies (Magnetti 2010). The cross references between these bodies of literature are minimal.

\section{Conclusions}

This paper documents the different shifts of power that are embedded in the new EU economic governance that is being implemented to deal with the effects of the euro and financial crisis. It is argued that a difference has to be made between vertical shifts delegating competences from the level of the member states governments to the European level, horizontal shifts of delegating competences to independent institutions and rules, and diagonal combinations of vertical and horizontal shifts. The economic frameworks for these shifts, respectively fiscal federalism and credibility, were sketched. Next the features of the types of shifts were discussed for the three policy domains that are covered by the new EU economic governance, i.e. fiscal policy, banking supervision and monetary policy. Finally an attempt was made to systematize the observed shifts and charting them in a framework consisting of two levels of government (national and European) and three methods of decisionmaking (discretion, rules and delegation). Charting shows that eight different kinds of power shifts are embedded in installing the new economic governance. The main impact of this variety of shifts is on accountability. The vertical shifts raise other questions than the horizontal shifts. The first kind refers to the discussions on the European democratic deficit, while the second kind refers to accountability in the context of discretion versus delegation. The analysis of these questions is for future research. 


\section{REFERENCES}

Balassa, B. (1961), The Theory of Economic Integration. London: Allen and Unwin. Banaian, K. (2008), "Measuring Central Bank Independence: Ordering, Ranking, or Scoring?," in K. Banaian and B.W. Roberts Jr. (eds.), The Design and Use of Political Economy Indicators. New York: Palgrave Macmillan, 33-55.

Beetsma, R., and L. Bovenberg (1999), "Does Monetary Unification Lead to Excessive Debt Accumulation?" Journal of Public Economics 74: 299-325.

Benz, A., and C. Zimmer (2010), “The EU's Competences: The 'Vertical' Perspective on the Multilevel System," Living Reviews in European Governance 5(1), http:// www.livingreviews.org//reg-2010-1.

Bogaert, H., L. Dobbelaere, et al. (2006), "Fiscal Councils, Independent Forecasts and the Budgetary Process: Lessons from the Belgian Case," Federal Planning Bureau Working Paper 4.

Cour-Thimann, P., and B. Winkler (2012), "The ECB's Non-standard Monetary Policy Measures: The Role of Institutional Factors and Financial Structure," Oxford Review of Economic Policy 28(4): 765-803.

Curtin, D. (2007), "Holding (Quasi-)autonomous EU Administrative Actors to Public Account," European Law Journal 13(4): 523-541.

de Haan, J. (1997), "The European Central Bank: Independence, Accountability and Strategy: A Review," Public Choice 93(3): 395-426.

de Haan, J., and S. C. W. Eijffinger (2000), "The Democratic Accountability of the European Central Bank: A Comment on Two Fairy-tales," Journal of Common Market Studies 38(3): 393-407.

De Prest, E., H. Geeroms, and G. Langenus (2012), "New Developments in the Economic Governance of the European Union," NBB Economic Review June: $102-120$.

Debrun, X., and M. S. Kumar (2008), "Fiscal Rules, Fiscal Councils and All That: Commitment Devices, Signaling Tools or Smokescreens?" Banca d'Italia, Fiscal Policy: Current Issues and Challenges, 479-510.

Debrun, X., D. Hauner, et al. (2009), "Independent Fiscal Agencies," Journal of Economic Surveys 23(1): 44-81.

Degryse, C. (2012), “The New European Economic Governance,” ETUI, November 14.

Draghi, M. (2013), "The Policy and the Role of the European Central Bank during the Crisis in the Euro Area," Speech at the Katholische Akademie in Bayern, Munich, 27 February.

Elliott, D. J. (2011), "An Overview of Macroprudential Policy and Countercyclical Capital Requirements," The Brookings Institution, March 10.

Elliott, D. J. (2012), "Key Issues on European Banking Union: Trade-offs and Some Recommendations." Retrieved from Brookings Institution: Global Economy and Development Working Paper 52.

EU (2011a), "Regulation (EU) No 1173 / 2011 of the European Parliament and of the Council of 16 November 2011 on the effective enforcement of budgetary surveillance in the euro area." 
EU (2011b), "Regulation (EU) No 1174 / 2011 of the European Parliament and of the Council of 16 November 2011 on enforcement measures to correct excessive macroeconomic imbalances in the euro area."

EU (2011c), "Regulation (EU) No 1175 / 2011 of the European Parliament and of the Council of 16 November 2011 amending Council Regulation (EC) No 1466 / 97 on the strengthening of the surveillance of budgetary positions and the surveillance and coordination of economic policies."

EU (2011d), "Regulation (EU) No 1176 / 2011 of the European Parliament and of the Council of 16 November 2011 on the prevention and correction of macroeconomic imbalances."

EU (2011e), "Council Regulation (EU) No 1177 / 2011 of 8 November 2011 amending Regulation (EC) No 1467 / 97 on speeding up and clarifying the implementation of the excessive deficit procedure."

EU (2011f), "Council Directive 2011 / 85 / EU of 8 November 2011 on requirements for budgetary frameworks of the Member States."

European Commission (2011), "Green Paper on the feasibility of introducing Stability Bonds." COM(2011) 818 final. Brussels, 23.11.2011.

European Commission (2012a), "Common principles on national fiscal correction mechanisms, Communication from the Commission," $\mathrm{COM(2012)} 342$ final, Brussels, 20.6.2012.

European Commission (2012b), "A Roadmap towards a Banking Union, Communication from the Commission to the European Parliament and the Council," $\operatorname{COM}(2012) 510$ final, Brussels, 12.9.2012.

European Commission (2013), "An important step towards a real banking union in Europe: Statement by Commissioner Michel Barnier following the trilogue agreement on the creation of the Single Supervisory Mechanism for the eurozone," Memo 13/251, 19 March.

Genoud, C. (2003), “Toward a Content and Contextual Approach of Delegation, or 'How and Why Should We Open the Regulation Black Box."' ECPR Joint Session Delegation in Contemporary Democracies. Edinburgh.

Gilardi, F. (2002), "Policy Credibility and Delegation of Regulatory Competencies to Independent Agencies: A Comparative Empirical Consideration," Journal of European Public Policy 9(6): 873-893.

Gilardi, F. (2006), “The Same, but Different. Central Banks, Regulatory Agencies and the Politics of Delegation to Independent Authorities," Political Science Working Paper Series, Université de Lausanne 25.

Goodfriend, M. (2012), “The Elusive Promise of Independent Central Banking," IMES Discussion Paper Series E-09, Institute for Monetary and Economic Studies, Bank of Japan.

Issing, O. (2012), “The Mayekawa Lecture: Central Banks - Paradise Lost," Monetary and Economic Studies, Institute for Monetary and Economic Studies, Bank of Japan, Vol. 30, November: 55-74.

Jensen, T. (2009), "The Democratic Deficit of the European Union," Living Reviews in Democracy. Most recent version accessible at http://www.livingreviews.org/ lrd-2009-2 
Keefer, P., and D. Stasavage (1998), "When Does Delegation Improve Credibility?" Central Bank Independence and the Separation of Powers, CSEA Working Paper Series 18 Oxford.

Kirkpatrick, C., D. Parker, et al. (2006), "Foreign Direct Investment in Infrastructure in Developing Countries: Does Regulation Make a Difference?" Transnational Corporations 5(1): 143-171.

Kopits, G., and S. Symansky (1998), "Fiscal Policy Rules," IMF Occasional Paper 162. Washington, D.C.: International Monetary Fund.

Kydland, F. E., and E. C. Prescott (1977), "Rules Rather than Discretion: The Inconsistency of Optimal Plans," Journal of Political Economy 85(1): 473-491.

Larsen, A., L. H. Pedersen, et al. (2006), "Independent Regulatory Authorities in European Electricity Markets," Energy Policy 34(17): 2858-2870.

Llewellyn, D. (1999), “The Economic Rationale for Financial Regulation.” FSA, Occasional Paper Series, No. 1.

Maggetti, M. (2010), "Legitimacy and Accountability of Independent Regulatory Agencies: A Critical Review in Living Reviews in Democracy." First published: November 2010. Most recent version available at http://www.livingreviews.org/ lrd-2010-4.

Majone, G. (1998), “Europe's 'Democratic Deficit:' The Question of Standards,” European Law Journal 4(1): 5-28.

Masciandaro, D., M. J. Nieto, and M. Quintyn (2011), "Exploring Governance of the New European Banking Authority - A Case for Harmonization?" Journal of Financial Stability 7: 204-214.

Meensel, L. V., and D. Dury (2008), "Nut en doelmatigheid van begrotingsregels en onafhankelijke begrotingsinstellingen," Economisch Tijdschrift NBB(Juni): 7390.

Millar, A. (2012), "EU Banking Union - Operational Issues and Design Considerations," Report prepared for the International Regulatory Strategy Group, October.

Moravcsik, A. (2002), "In Defence of the 'Democratic Deficit': Reassessing Legitimacy in the European Union," Journal of Common Market Studies 40(4): 60324.

Musgrave, R. A. (1959), The Theory of Public Finance: A Study in Public Economy. New York: McGraw-Hill.

Richter, F., and P. Wahl (2011), "The Role of the European Central Bank in the Financial Crash and the Crisis of the Euro-Zone," Report based on a WEED Expert Meeting, Berlin.

s.n. (2013), "Laat Europa beslissen in plaats van begrotingszondaars," De Standaard, 8/5.

Taylor, J.B. (2013), “The Effectiveness of Central Bank Independence versus Policy Rules," Prepared for the session Central Bank Independence: Reality or Myth? American Economic Association, Annual Meeting, San Diego, CA, January.

Van Rompuy, H. (2012), "Towards a Genuine Economic and Monetary Union," 5 December. 